\title{
Local perceptions of land-use change: using participatory art to reveal direct and indirect socioenvironmental effects of land acquisitions in Kilombero Valley, Tanzania
}

\author{
Emma L. Johansson ${ }^{1}$ and Ellinor Isgren ${ }^{2}$
}

\begin{abstract}
In this study, we combine conventional qualitative approaches with a more novel approach, participatory art, to explore local perceptions of land-use change and future aspirations for development in two communities in Kilombero Valley, Tanzania. We concentrate on the effects of large-scale land acquisitions on people and the environment in an ecologically important area. Leasing of land to foreign agribusinesses for the production of timber, food, and fuel crops has created a politically charged debate with strong ideologies on both sides, and people directly impacted are not the ones driving the debate. Local farmers, fishermen, and pastoralists were cued about landscape and livelihood changes through focus-group discussions, interviews, and by cocreating paintings of the past, present, and future. Findings reveal that art can make a valuable methodological contribution for understanding and communicating complex interactions between drivers of change and their socioenvironmental impacts, and for exploring desirable future visions.
\end{abstract}

Key Words: land grabbing; land-use change; large-scale land acquisitions; participatory art

\section{INTRODUCTION}

In recent decades, we have witnessed an escalation of sustainability challenges across the world that impact people and the environment in different ways, including climate change, water scarcity, natural disasters, inequality, and resource conflicts (Kates and Parris 2003). Land-use and land-cover change are both drivers and solutions to many of these challenges. Land-use change is a key processes by which humans influence the functioning of the Earth system, contributing to environmental change and in turn affecting people (Turner et al. 2007, Lambin and Meyfroidt 2011). Particularly vulnerable are people who are poor and live directly off the land as small-scale farmers, but these groups often have little power to influence decisions affecting their society and surrounding environment (Bryant 1998). About 80\% of the population in Tanzania reside in rural areas and depend on agriculture for their livelihoods, making the availability and accessibility of land very important (Mombo 2011). In recent years, there has been a rise in foreign direct investment in agricultural land, often seen as part of the "global land grab" (Zoomers 2010). In this paper, we respond to the call for more participatory methodological approaches for better understanding effects of large-scale land acquisitions (Scoones et al. 2013). The aim of this research is to focus on perceptions and lived experiences of land-use change within communities in Kilombero Valley, where foreign agribusinesses have acquired land, and thus contribute to the wider debate on how large-scale land acquisitions can be understood from a bottom-up perspective. In order to achieve this aim, we address the following questions: (1) what are the local perceptions of socioenvironmental change, and what is the role of large-scale land acquisitions? (2) What is the usefulness of participatory art as a method to facilitate discussions and visualize socioenvironmental change and future aspirations within communities where land is leased?

This article is structured into five sections. In the introduction, we elaborate on the issue of large-scale land acquisitions, particularly in Tanzania, why local participation is needed in knowledge production about their socioenvironmental impacts, and the potential value of introducing new methodological tools such as art. The next section provides a description of the fieldwork area. In the third part, we describe the methods used in the fieldwork; the fourth section synthesizes the findings from the two different sites. In the fifth section, we discuss and reflect on both the findings and the methodological approach. Finally, we offer some concluding remarks and suggestions for future research.

\section{Large-scale land acquisitions as a driver of land-use change}

Large-scale agroindustrial expansion is now a dominant driver of land-use change, and the demand for agricultural products is expected to increase by $50 \%$ by 2050 (Gibbs et al. 2010). Agriculture is also the biggest freshwater user, responsible for $70 \%$ of global freshwater withdrawals (Shiklomanov 2000). Environmental impacts from agriculture range from local to global and include losses in carbon storage, wildlife habitat, and degradation of watersheds (Gibbs et al. 2010). This has negative implications for biogeochemical and biophysical climate regulation, as well as for people who critically depend on terrestrial and aquatic ecosystems for food and freshwater provision (Foley et al. 2005).

Tanzania is one among many African countries experiencing renewed interest in large-scale investment in agricultural land (Nelson et al. 2012). The Tanzanian government has played an active role in attracting such investments for a long time (Alden Wily 2012), and land contracts of 33,66, or 99 years have been given to transnational and domestic large-scale agribusinesses to grow cash crops like sugarcane, rice, maize, vegetables, and various high-value tree crops (Locher and Sulle 2013).

Following the intensified commercial interest in agricultural land, there has been a surge of research into its geography, scale, drivers, and impacts. Also, public media and civil society organizations have taken part in the debate, which has come to be highly polarized (Cotula et al. 2014). Should large-scale investments be 
welcomed because they can assist transition toward more modern and productive agriculture, or should they be curbed because they represent nothing more than "neocolonial theft" of local livelihoods without significantly contributing to national economic development (Toft 2013)? Many scholars have called for more research on the impacts of land deals within national and local contexts to create a stronger basis for decision making around them (Borras et al. 2011, Hunsberger et al. 2015). However, assessing impacts of land acquisitions is notoriously difficult; there is often a lack of reliable baselines, impacts are socially heterogeneous and change over time, and they interact with other pressures on land (Cotula et al. 2014, Oya 2013). Scoones et al. (2013) warn that the "literature rush" that has accompanied the "land rush" has led to a bigger but not always better picture of the phenomenon. They argue that the problem is methodological, agreeing with Edelman (2013) that research has been overly "hectare-centric," and call for a second phase of research that favors more grounded and specific approaches. Aggregate measures of the extent and patterns of land trade and well-designed quantitative surveys of their impacts are undoubtedly important, but there is a need to complement these with participatory approaches that allow researchers to become "conduits for local voices rather than replacing them" (Scoones et al. 2013: 479).

\section{Local participation in knowledge production about land acquisitions}

Although a substantial body of scholarly work around large-scale land acquisitions has emerged, people actually affected rarely determine the focus of research, and the most pressing socioenvironmental issues in particular locations may get overlooked. Furthermore, when focusing solely on the mechanisms and impacts of investments - which are also important-the question of alternative approaches to agricultural development beyond foreign investment in largescale projects gets overlooked (de Schutter 2011). This also applies to appropriate responses and desirable alternatives from the perspectives of impacted communities once foreign companies are in place. When pathways to sustainability are understood as multiple and place specific, research needs to span spatial and temporal scales to reflect the complexity in human and natural interactions. There is a need to recognize the wide range of perceptions and preferences of relevant societal actors, not least those who are most impacted by, and vulnerable to, social and environmental change (Schneider and Rist 2013). This also necessitates "decolonizing" research to reduce the power imbalance in knowledge production (Cook 2015), especially when there are large cultural differences between researchers and the researched. Through innovative participatory methodologies, many aspects can be included that otherwise would not be considered by the researcher, such as local forms of knowledge and normative values (Swart et al. 2004). Indigenous observations can strengthen land-change research as a rich source of environmental history and as a framework for formulating research questions because they provide a valuable opportunity to uncover local concerns (Nightingale 2003, Carothers et al. 2014). Participatory methodologies have thereby been argued to be empowering, for example by legitimizing local knowledge, involving marginalized groups in joint learning processes, and drawing attention to issues affecting them (Chambers 1994, Enfors et al. 2008).

Much conventional research involves some form of "participation." What sets apart explicitly "participatory" research, Cornwall and Jewkes (1995) argue, is the ambition to shift the location of power in the research process. In part a response to reductionist scientific approaches, participatory research also acknowledges the complexity of local situations and knowledge gained through everyday life (Glassman and Erdem 2014, Brydon-Miller et al. 2003, Gaventa and Cornwall 2006). Participatory approaches are found in many academic disciplines, especially within development and sustainability research (Lang et al. 2012, Brandt et al. 2013). In the context of socioenvironmental change, participation can increase affected people's ability to influence knowledge generation and decision making and to insert their knowledge into the public discourse (Cook 2015). More an "attitude or approach" than a series of techniques, participatory research often seeks to expand the repertoire of research activities to include different forms of art and storytelling, often in combination with more conventional methods (Cornwall and Jewkes 1995). Participation can be brought about in a wide variety of ways, with different purposes, agendas, and implications. This research approach is certainly not without problems and pitfalls, requiring a high degree of reflexivity (Pain and Francis 2003).

\section{Art in participatory research}

Art and science both attempt to capture the world around us in creative and innovative ways to create novel knowledge and awareness. Integrating arts into research can be a way to synthesize complex issues, improve communication, and construct new integrative narratives by engaging audiences from different cultural contexts (Curtis 2011, Heras and Tàbara 2014, Streck 2014). The use of art in research is often discussed as a matter of finding new ways to close the gap between awareness and behavior, as art has the potential to emotionally, intuitively, and cognitively evoke change and thus "speed up" sustainable societal transformation, as hypothesized by Heras and Tàbara (2014). But creating art through collaborative processes is also a way to elicit knowledge, values, and emotions, a central objective of qualitative research. As a methodology, participatory art can provide a platform for discussion and a "shared space," which is more familiar to many people than conventional research activities (Zurba and Berkes 2013). Although the process is as important as the product, the material outcome can form a "boundary object" that takes on different meanings for different actors (researcher, participants, viewers) but facilitates communication between them (Star and Griesemer 1989). Furthermore, visual art is useful for creating future visions, which are increasingly used in order to explore socioenvironmental effects of human-induced land-use change, such as trade-offs between ecosystem services and human wellbeing (Palomo et al. 2011, Hanspach et al. 2014, Oteros-Rozas et al. 2015). A vision is a type of scenario that describes desirable future states without making predictions. Visioning can stimulate creative thinking about the future and is often combined with stakeholder involvement, for instance to take into account local people's knowledge and preferences, and identify possible pathways to reach that future (Schneider and Rist 2013, Wiek and Iwaniec 2014). 
To sum up, land-use change associated with large-scale land acquisition is an area of research that would benefit from methodological expansion toward novel qualitative and participatory approaches, as it (1) allows people who are affected yet underrepresented to influence the research focus and uncover local concerns that can be further researched, (2) creates a platform to explore desirable alternatives and preferences expressed by the people in place, and (3) helps to understand and communicate the complexity of situated human-nature interactions and lived experiences by people who are dependent on and vulnerable to (but could also benefit from) social and environmental change. Joint production of visual art is one possible way of complementing conventional research methods as it enriches discussions and communication both during and after fieldwork. Participatory art workshops were used in this study as a means to explore how people perceive the past, present, and future in relation to socioenvironmental change.

\section{METHODS}

The fieldwork is exploratory and participatory both in its aim and design and is inspired by methods from ethnography and participatory rural appraisal (Chambers 1994). The fieldwork decisions were made in collaboration with people in Tanzania, with the initial criteria that the case-study areas should experience land-use change due to large-scale land acquisitions and that the companies should be in operation (not in the start-up phase or abandoned). The ultimate aim was to let people in communities adjacent to land acquisitions share their perceptions of land-use change and guide the focus of the research toward issues that are of concern for them, within the domain of environmental change and human-nature interactions. This exploratory approach can strengthen research as a framework for formulating research questions that are based on local concerns and conditions (Carothers et al. 2014).

\section{Study area}

The fieldwork was done in March to May 2015 in Kilombero Valley, Tanzania, in villages where transnational agribusinesses have acquired land within their village boundaries. The site was chosen because of the rapidly increasing pressure on natural resources due to a rising transnational and national interest to convert land into large-scale agriculture and timber production. Kilombero Valley is referred to as the Breadbasket of East Africa due to its ideal conditions for agriculture with year-round warm temperatures, fertile soils, and abundance of water (Mombo et al. 2011). It is a biodiversity hotspot and has one of the largest freshwater wetlands in East Africa (Kangalaweand Liwenga $2005 b$ ). There is a growing international interest to protect the biodiversity of Kilombero Valley, and the floodplain was declared as a Ramsar site in 2002 and is thereby protected under the Convention on Wetlands of International Importance. The wetlands are important for indigenous communities who traditionally use the land for farming (common crops include rice, maize, oil palm, banana), fishing, and grazing (Kangalawe and Liwenga 2005a).

The fieldwork was conducted in two case-study areas, located in the Kilombero and Ulanga Districts. In the first site, Kilombero Plantations Limited (KPL) have acquired 5800 ha of land since 2007 with a 99 -year contract for rice production. In the second site, Kilombero Valley Teak Company (KVTC) have acquired land since 1992 and currently have a 99-year contract for teak production on 28,132 ha of land. KVTC is planting around 8000 ha of the acquired land with teak because the remaining valley land and highland are not suitable for teak production.

\section{Focus-group discussions}

Focus group discussions were held in five villages (three for KPL and two for KVTC) in order to get an initial overview of the area and of different people's perceptions of environmental change. The focus groups deliberately included farmers, fishermen, and pastoralists, young and old, men and women. Fishermen and pastoralists are often also engaged in farming. The questions were open ended in order to cocreate a narrative about how natural resources have changed, reasons for change, and how different livelihood practices are affected by the environmental change; furthermore, we cued about future aspirations for development. Following this, additional focus-group discussions were held with fishermen and pastoralists because they were underrepresented later on in the painting process due to distance and time constraints. The focus-group discussions formed the basis for the painting workshops in that they provided the main concerns and stories of change. In total, seven focus-group discussions were held: five with mixed participants, one with pastoralists, and one with fishermen.

\section{Painting workshops}

We arranged painting workshops in two villages, one that leases land to KPL and one to KVTC. The first workshop was held in the village where most land has been acquired by KPL, whereas the second village was chosen according to what was most practical regarding distance, time, and accessibility (KVTC). In each village, we made three paintings, representing the past, present, and future. The paintings were made outside the village office, and each painting took around $4 \mathrm{~d}$ to complete, providing plenty of opportunities to discuss the process, content, and issues being painted-both with participants and with community members passing by.

The participants in the painting workshops (one woman and one man per painting) were selected from the focus groups based on interest and availability. If no focus-group members could participate, we asked a woman or man of a certain age, depending on who was underrepresented (Fig. 1). These participants were interviewed and informed about the general outcomes of the previous focus-group discussion. At first, the aim was to have three participants per painting, representing all livelihood groups. However, because of the distance to the center of the village, it was difficult for pastoralists and fishermen to participate beyond the focus groups. Although these livelihood groups were represented in the paintings - as the focus groups formed the basis of the painting workshop - there is a risk that their perceptions might be less emphasized.

Inspiration for the paintings was drawn from the Tanzanian art style "tinga-tinga," a common art style with roots in African tradition that generally has storytelling motives of animals and people in a Tanzanian environment. This style was chosen because of its familiarity and because of its ability to capture human activities and interaction with natural resources. The role of the artist was to instruct the participants how to paint and to make decisions on the aesthetics, but with input from the participants on how the different elements should look. The role of the 
Fig. 1. The methodological process for the two case-study areas, showing the livelihood and gender (male (m), female (f)) distribution of the participants of focus-group discussions and interviews. The figure also highlights which focus groups formed the basis for the two painting workshops and if participants were previously part of the focus group or included through interviews.
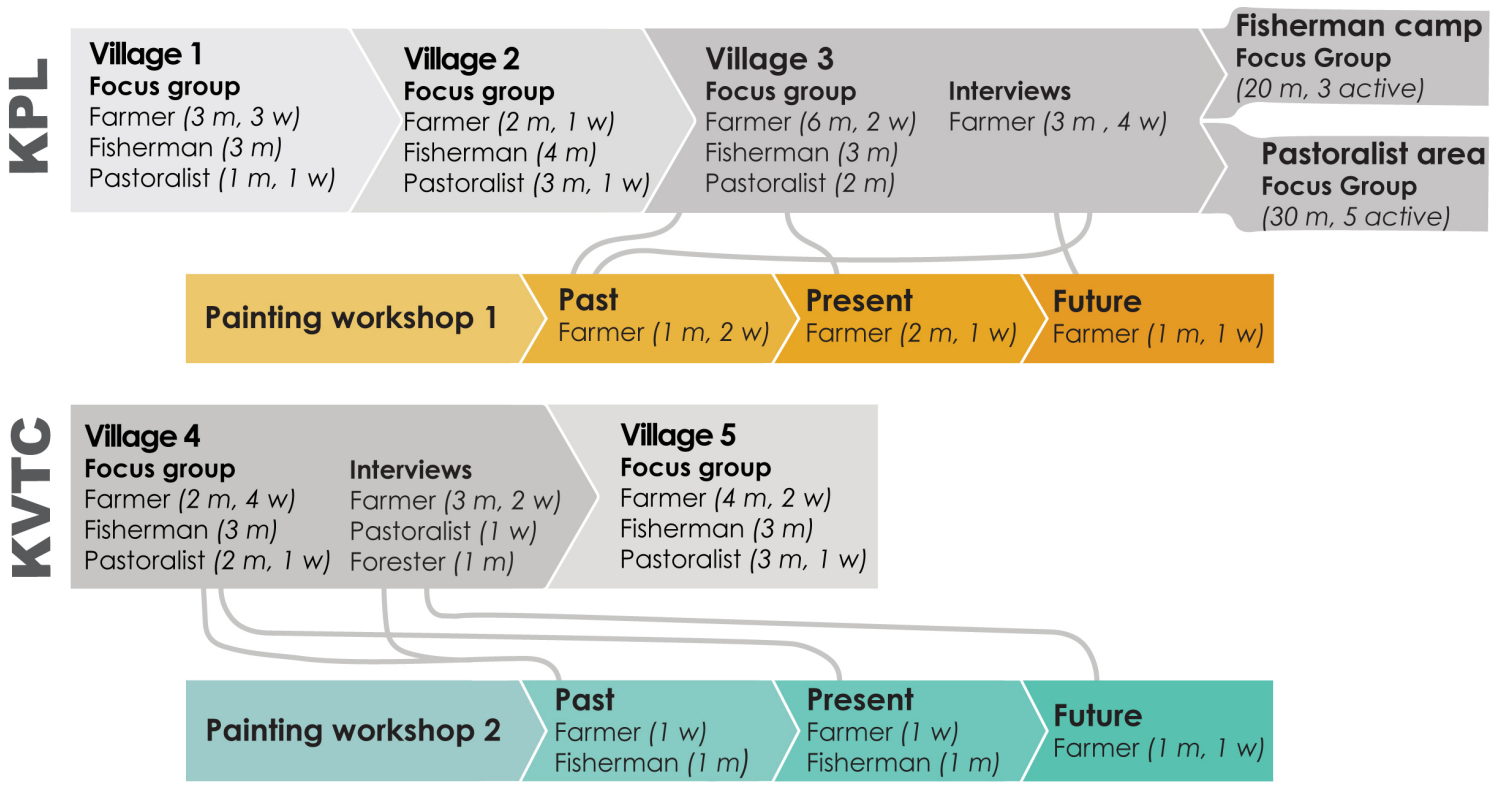

researcher was to facilitate discussions and storytelling, but also to take part of the painting process and ensure that all participants were equally included. Based on the focus-group discussions, the participants were asked to explain and visualize: (1) How their village and surrounding environment currently is affected by land use, in terms of natural resources and human activities. (2) How their village and surrounding environment was before land was acquired in the village, in terms of natural resources and human activities. (3) What future aspirations they have for their village and surrounding environment, in terms of natural resources and human activities.

This focus on three different time periods is a means to capture how people perceive and experience changes in their environment, including the relationship between community and land use. In the following sections, we will explain, in general terms, how the paintings were made.

\section{Painting process}

We started by painting the present, serving as a baseline for describing the past and thinking about the future (e.g., more/less, better/worse). The process began by the artist and participants making a sketch on paper of where things are located in relation to each other: e.g., mountains, rivers, main roads, settlements, company site, grazing areas, and wetlands. Then we transferred the sketch to the canvas to paint how the environment looks today, to finally add the human activities and stories about interactions between the company, community, and environment. The motif was based on what was brought up during the focus-group discussions, but people that passed by the village office (where we were painting) also added, edited, and confirmed stories in the painting. The next step of the workshop was to paint the past. We agreed that the past should represent the time just before the foreign company acquired land in the village. As the first village has a history of many companies, we agreed to focus on the time just before the arrival of KPL. Two older people participated in painting the past because they have a better idea about the past than the youth. The same landscape was painted, but now rivers, forest, and settlements were resized and replaced in relation to the current situation and location. Human activities were also painted in relation to the current situation in order to visualize the changes for different livelihoods. Finally, we made a painting of future aspirations, and for this painting, two young farmers participated. As none of these participants had been part of the previous focus-group discussion, we informed them about what had been said and also encouraged them to ask other people about how they want the future to develop in order to spur their imagination.

\section{Observations and additional interviews}

Both villages were observed and explored by foot, bicycle, and motorbike, which allowed easy access to various locations in order to get acquainted with the environment, meet people to observe and learn about how they live and use the land and other natural resources. Additionally, during the $2-3$ weeks in each village, open-ended interviews were held with stakeholders that in various ways are engaged in development and land-use change of the Kilombero Valley (company employees, research institutes, district ministries, NGOs). The purpose of engaging with actors outside the village boundaries was to get an overview of how focus-group participants' perceptions about patterns and processes compare with the perceptions among people who work with wetland protection, large-scale agriculture, and Kilombero district administration. This was not an attempt to validate or reject local perceptions, but rather to deepen our analysis of how these can be used to understand socioenvironmental change. 
Fig. 2. General schematic of common features identified in both case-study areas regarding how land use is impacted and impacting on the environment and human wellbeing due to the higher pressure on land. The green square is the central part of the analysis, representing land availability for livelihoods. The yellow circles are the main pressures that affect land availability. The noncolored words are processes that are changing the state of the environment (dark blue) and people's "wellbeing" (light blue) as an effect of the increased pressure on land.

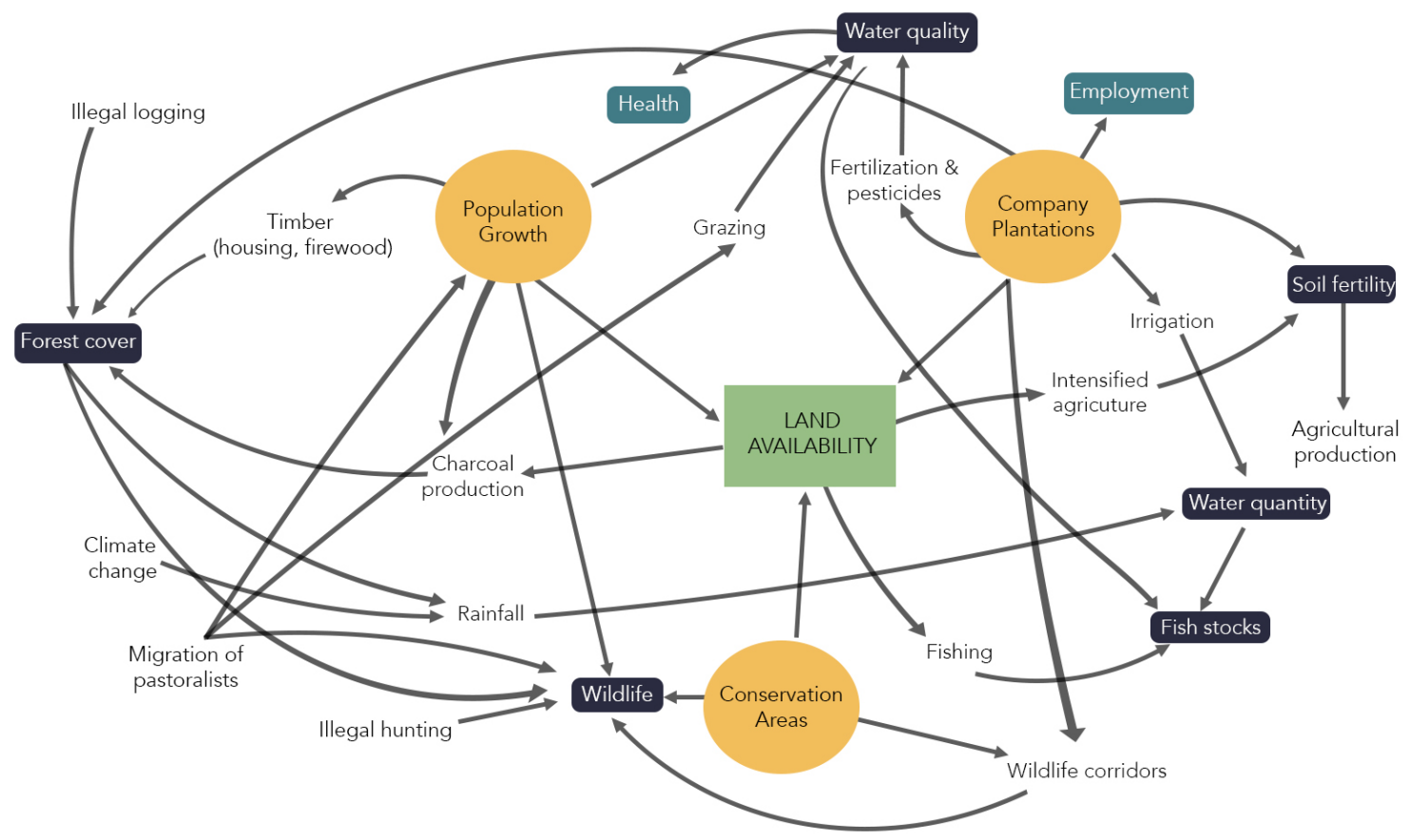

\section{Analyzing and synthesizing the material}

Analysis began during fieldwork when information from the focus-group discussions was translated into paintings, and the paintings in turn were viewed, explained, and discussed. In this way, participants not only contributed with data but also took part of interpreting it. After fieldwork, analysis was continued using audio recordings, notes, and the paintings. The focus was to identify how the use of land in the study areas has changed over time, and with what social and environmental impacts. In the presentation of findings, we display the paintings alongside a synthesized textual narrative and a generalized schematic of how different socioenvironmental processes affect natural resources. The schematic aims to introduce the reader to dominant processes and outcomes that can be generalized from both sites. The figures of the future paintings contain numbers in order to more easily connect the visualized objects with the textual narrative as these objects tend to be more symbolic representations of change than the paintings of the past and present.

\section{RESULTS}

\section{Overview}

The outcome of the focus-group discussions, interviews, and painting workshops shows that, in both cases, local communities have experienced an increased pressure on land and water resources during the past decades. Figure 2 synthesizes and illustrates the dominant pressures and processes as explained by the people participating in the discussions. Multiple causes of change were pointed out, including population growth, inmigration of people and cattle, increase of nature conservation areas, and large-scale transnational and domestic agricultural businesses. These pressures have been exacerbated by climatological challenges like higher frequency of droughts. The increased pressure on land and water changes the availability and accessibility of natural resources for local communities, thus creating new socioeconomic challenges, as few local residents have been able to find satisfactory alternatives to their traditional livelihoods of farming, fishing, and animal husbandry.

\section{Visualizing the change from past to present}

The paintings of the past and the present point to environmental changes, including deforestation, decreased water availability (and fish stock) in rivers, reduced wildlife, and decreased land available for farming (Figs. 3, 4). The participants traced these changes to both land acquisitions and population growth. Population growth was consistently described as the main driver of increased pressure on natural resources, both from a high natural growth rate, but also due to rapid in-migration of pastoralists during the last decade. This falls in line with census data that show that Kilombero and Ulanga Districts have experienced a $24 \%$ and $26 \%$ growth, respectively, in rural population from 2002 to 2012 (National Bureau of Statistics (NBST) 2012). The presence of the companies has had both direct and indirect effects on natural resources. Direct effects include reduced water levels in rivers due to irrigation or introduction of tree species with high water requirements. Indirect effects include 
deforestation and lower fish stocks in the rivers because people have lost access to land where they used to farm (causing them to shift to fishing), swamps where they used to fish, and shrublands where they fetched firewood. The participants further believe that deforestation affects the rainfall patterns and contributes to lower water levels in the rivers. The reduction of wildlife is seen as an effect of company interference with previous habitats and migration routes, as well as expansion of farming areas and village settlements to the wetland area (due to population growth and land leased to the company). Similar observations were made by Rovero and Jones (2012), who found that the main migration route between the Udzungwa Mountains and Selous game reserve has lost connectivity during the last decade and became closed in 2010. They suggest that the main causes of disruption are increased cattle, high human immigration into the corridor area, and conversion of land to farming and grazing.

Fig. 3. The paintings of the past (top) and present (bottom) situation of Mkangawalo Village, where KPL is growing and processing rice. The past represents about 10 years ago. The main changes seen in the paintings are reductions in forest cover, water quantity, and number of wildlife; an increased population and migration of pastoralists and cattle; and a shift of farms and settlements to the wetlands due to the reduced land availability caused by the agribusiness.
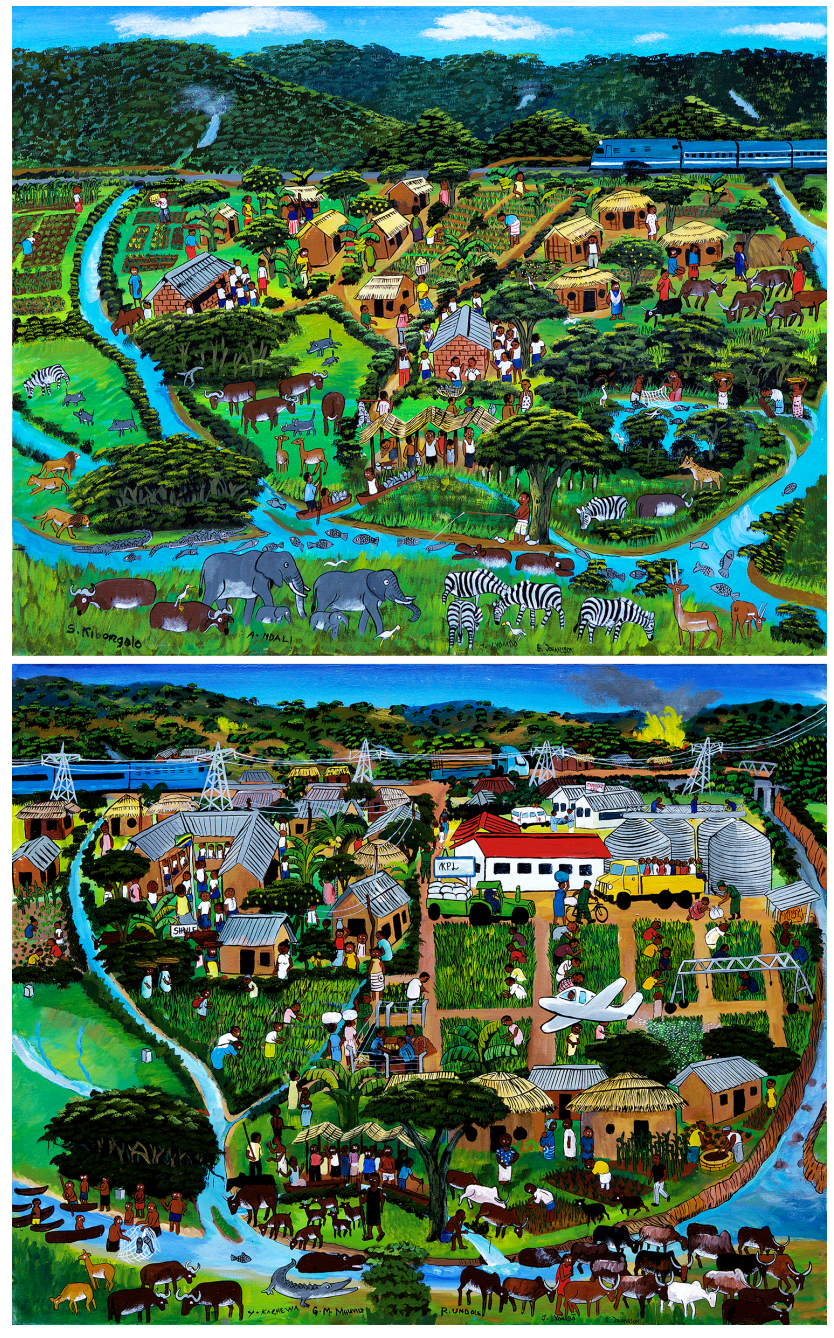

Fig. 4. The paintings of the past (top) and present (bottom) situation of Nakafulu Village, where KVTC is growing teak trees in the uplands. The past represents about 30 years ago. The main changes seen in the paintings are the reductions in natural forest cover (replaced with teak trees), water quantity, wildlife numbers, and yields; an increased population and migration of pastoralists; and an expansion of rice fields to the wetland area.
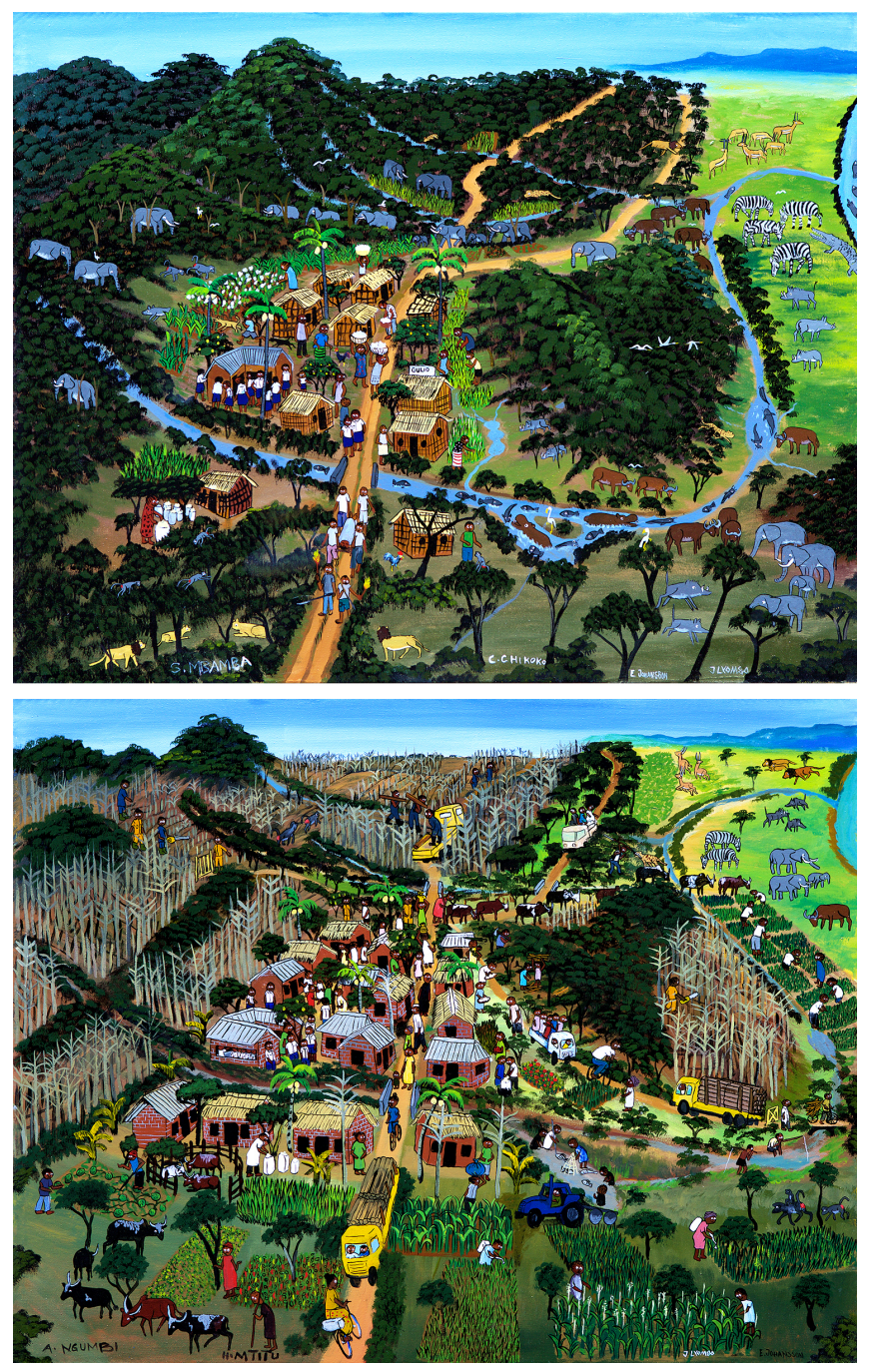

The societal changes described by participants refer to how people use the land and how they are affected by environmental change and the presence of the companies. The dominant stories relate to reduced access to farmlands, accusations and punishment for stealing from the company plantations, as well as negative impacts on health and crop yields. Accessibility of farmlands has decreased for multiple reasons: Firstly, the village rice fields have expanded due to population growth. Secondly, land leases have influenced the location of village rice fields. In the case of KPL, the company's arrival has forced a shift toward the Ramsar wetland area that is distant from the permanent settlements. In the case of KVTC, the lease prevents farmers from expanding 
their fields into areas that they would prefer for rice production. Here, participants expressed that if they had known how much population in the area would grow, they would not have given up this land at the time when the company arrived. Thirdly, the roads and paths to access these areas have been cut off by company roads and ditches that local people are not allowed to use. In the case of KPL, this ties in with the stories about accusations of theft, as farmers use the company roads to carry rice from the distant fields to the village center. When doing so, company guards accuse them of stealing rice (which also occurs), confiscate their harvest, and sometimes beat them. Impacts on health and yields are mainly believed to be caused by the spread of pesticides, herbicides, and fertilizers by aircraft in the case of KPL, but also due to the belief that the teak trees, in the case of KVTC, drain the soils of water and nutrients. One of the participants also mentioned that the pollinating insect species have changed since teak trees were introduced in the area, suggesting that this also may have reduced yields of rice and maize. This is not likely to be the reason for declining yields as these crops are wind pollinated (McGregor 1976), but could, however, be the case for crops like beans, cotton, peanuts, and soybeans that benefit from insect pollination. Finally, community members are dissatisfied with the low wages and insecure employment offered by the companies (seasonal employment involving planting, weeding, and harvesting), but few see any other alternatives than to work for them. The low wages (e.g., \$2 a day for KPL) is not a sufficient alternative to small-scale farming or fishing, but many see no other option than to accept temporary employment as farming is more challenging due to the increased pressures on land and water.

\section{The future}

As visualized in the paintings (Figs. 5, 6), participants from the two communities share similar future aspirations in the form of infrastructure development, restoration of natural resources, and increased participation and authority over company decisions. The last point is, in both cases, illustrated with a mango tree where local community members can openly meet with company representatives (number 1 in Figs. 5 and 6). Desired infrastructure improvements include paved roads, access to electricity, and improved houses. They also show that farmers want some mechanization of agriculture through the use of tractors. To reduce the impacts on water bodies, the participants suggest that KVTC should increase the buffer zone and replant native tree species along rivers (number 3 in Fig. 6). For KPL, most community members want the irrigation to stop (number 3 in Fig. 5), but the opinions differ, and some participants say that the company should maintain irrigation at the current level or even increase irrigation. In the village that leases land to KPL, people want illegal fishing to stop by having patrols in the fishing area and banning the use of illegal fishing tools (number 6 in Fig. 5). They want increased protection of the forests (be it from foreign companies, illegal logging, or other pressures) in order to stabilize rainfall patterns, and believe that wildlife will return if the environment is better taken care of. They also believe that the reduced water quality can be improved by assigning a specific area for grazing, and farmers stress that pastoralists should reduce the number of cattle (number 2 in Fig. 5). This view is not shared by the pastoralists, who acknowledge the impacts on water but do not want to change their herding practices.
Fig. 5. Future aspirations of the participants in Mkangawalo Village. The youth want the company to stay, but only if they have increased participation and authority over company decisions (1) and better working conditions (3). They want the pastoralists to reduce the number of cattle and to graze the animals in a specific area in order to improve water quality of the rivers (2) and they want illegal fishing to stop by having patrols in the river (6). They suggest fishponds, beekeeping, and a small-scale oil palm factory as alternative incomes $(4,5)$.

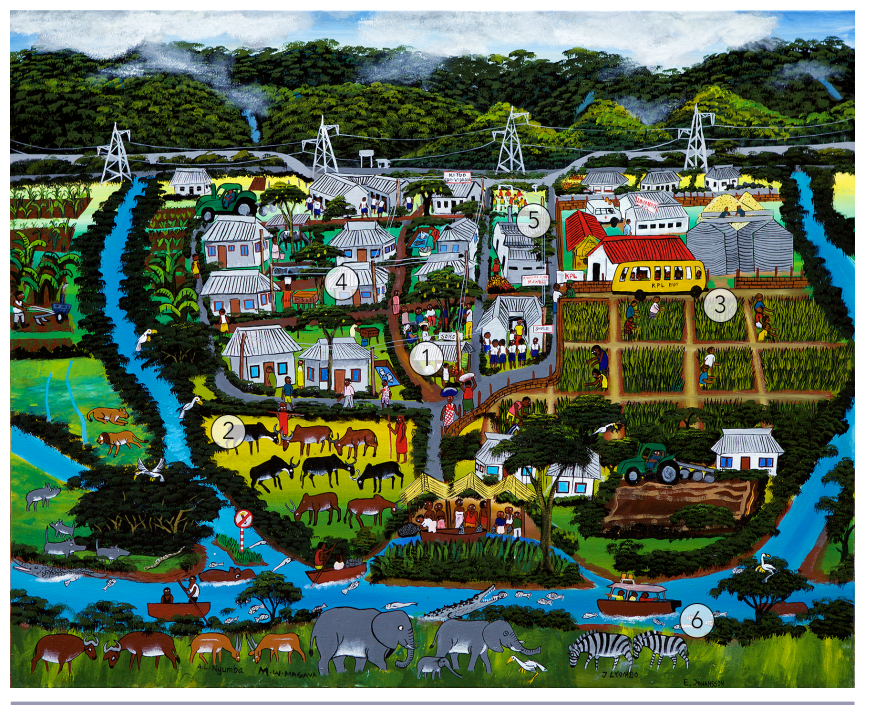

Fig. 6. Future aspirations of participants in Nakafulu Village. Here, also, the youth want the company to stay, but only if they have increased participation and authority over company decisions (1). They want the company to increase the buffer zone along the rivers and replant natural vegetation to improve water quantity and quality $(2,3)$. They suggest that the company should give back the land they are not using in order for farmers to grow rice (4).

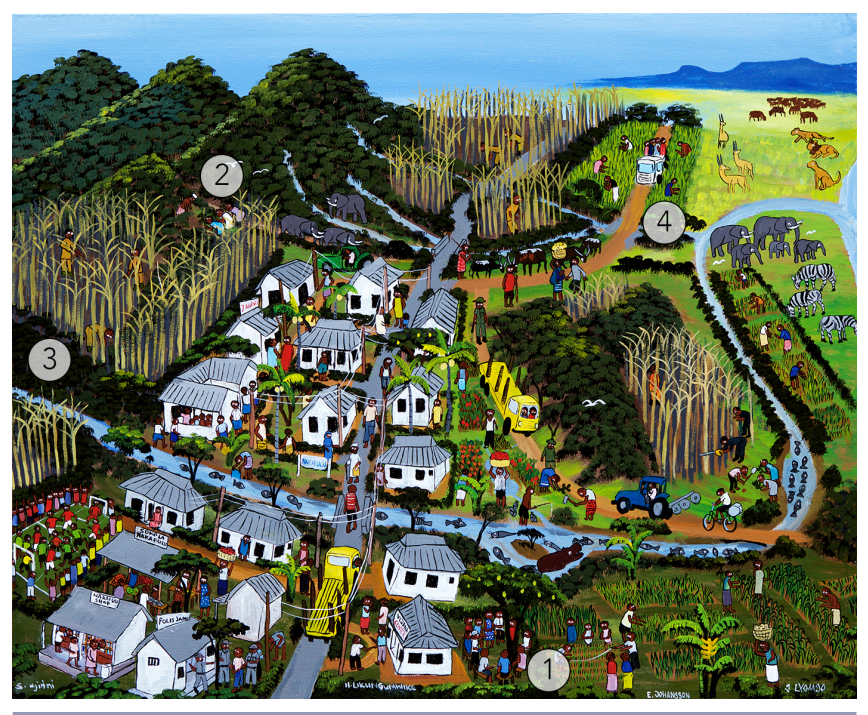


Participants also have several suggestions for alternative incomes, such as fishponds, beekeeping, and a small-scale oil palm factory (numbers 4 and 5 in Fig. 5). In the village that leases land to KVTC, many people want the company to give back the valley land that they are not using for teak production so that farmers can expand their rice fields (number 4 in Fig. 6). Important to note is that, in both sites, the youth who were part of the painting process wanted the companies to stay, but only if they offer fair and secure employment for local residents (number 3 in Fig. 5). Older people could generally not see any benefits from the presence of the companies in their current form and were concerned for younger generations, but felt powerless due to government support of the companies. If they had the power, they would want the companies to leave or only act as a buyer while leaving production to the local farmers. Contrasting future aspirations like presence of the company, irrigation, and grazing of cattle were dealt with in different ways - by focusing on the aspirations of the youth (presence of the company), the main aspiration (irrigation), or the only suggested alternative to a current challenge (grazing and number of cattle).

\section{DISCUSSION}

\section{Reflections on the findings}

Visualizing the past, present, and future through participatory art, in combination with conventional methods such as focusgroup discussions, interviews, and observations helped us understand changing land use (e.g., its directionality, drivers, and impacts) from a landscape and livelihood perspective. In both case-study areas, land acquisitions represent one of the main drivers of changing socioenvironmental conditions, with direct and indirect effects that constantly influence each other and reshape the current state. Furthermore, participants rarely pointed out the companies as the only cause of environmental change, but also highlighted the consequences of population increase and expansion of conservation areas, which have an added effect on land available for livelihoods. It is, therefore, important to approach this phenomenon not in isolation, but as an additional pressure on communities that already have to cope with a variety of stressors. We found that local community members are often well aware of (and openly point out) multiple stressors, including those in which they themselves play a role.

An example of direct effect of changed land use from natural forests to teak is the perceived effects on yields of staple crops. Multiple causes were pointed out, including a change in pollinating insects and concerns that teak trees might absorb nutrients and water from the soils. An example of indirect effects is the increased pressure on forest resources and its connection to rainfall and water quantity in the rivers. In the case of KPL, the company itself is not engaging in deforestation, but their presence has forced local communities to encroach on the forest reserve for fetching firewood and timber. In combination with population growth, this has caused rapid illegal deforestation during the last decade, which might have shifted local rainfall patterns and decreased the volume of water in the rivers. On top of this, it is believed that the company further reduces river flows through irrigation. Our claim here is that the companies are not always directly responsible for environmental degradation in the valley, but that they must also be understood as an indirect force of societal and environmental change.
The study also shows that even when the arrival of companies is identified as a cause of environmental degradation and harassment while offering few economic benefits, removal of the company is not necessarily seen as the desired solution, especially among youth. Communities may instead wish for greater consideration of environmental impacts, decent employment opportunities, and influence on decision making. Many participants wish for a renegotiation of the 99-year lease as unforeseen population conditions have increased the pressure on land. Meeting the above conditions does not mean that large-scale land acquisitions of this type are fully accepted locally or should be considered as the only path to agricultural developmentdetermining what interventions are best suited to sustainably fulfill national and local development aspirations is beyond the scope of this paper. What can be said, though, is that it is important to not make assumptions about what kinds of solutions those already impacted by land acquisitions wish to see. The alternatives to undesirable change do not need to equal reversal to past conditions.

\section{Reflections on participatory knowledge production}

The paintings are not meant to quantify land-system changes, but rather to visualize local perceptions of socioenvironmental change. Quantification of land-use and land-cover change are conventionally done by using methods like remote sensing and GIS, but these methods are incapable of capturing socioenvironmental change as experienced at the local level. By using participatory methods, we do not claim that the stories told by community members - or any other actors - should be taken at face value, but rather that lived experiences of socioenvironmental change are important both ethically and scientifically. This is particularly valuable when few data are available, making local knowledge indispensable for understanding both historical and current conditions. We recognize that local knowledge sometimes is insufficient in isolation (Riedlinger and Berkes 2001), and that people's memories and descriptions of past landscapes can be an unreliable source of accurate information about land-use change. Memories are selective and may be shaped less by actual observations of the physical environment than by interactions with past and current authorities, or individual experiences of economic hardship and scarcity (Boerma 2012). People might glorify the past, and some claims might be rumors and speculations. That said, even though participants' perceptions do not always coincide with "reality," it is their "subjective reality," that is shaping current and future behavior and land-system changes (Nightingale 2003, 2015). An example is a story about beacons that have been put up in the wetlands (middle left part of the painting of the present in Fig. 3). Several informants were very concerned that parts of the protected wetlands in the village have been leased to a foreign company. This was denied by an interviewee at the Ramsar office, who stated that the beacons mark where local farmers are not allowed to encroach. However, although it can be difficult for researchers to know if accounts are "correct," they can still be analytically valuable. The subjective reality described in this story says something about the (lack of) power and insight the local farmers have over land use and control, and their fear of further loss of land to investors.

Similar reservations can be held regarding participatory approaches for visioning the future; what is to say that "local" 
visions are feasible, sustainable, or just? It is important to note that this type of visioning exercise does not aim to make predictions, or identify an ideal development pathway as in the case of explicit "sustainability visions" (Wiek and Iwaniec 2014). Rather, we see it as a way to start exploring alternatives and solutions to socioenvironmental problems from the viewpoint of groups that are underrepresented in the debates concerning development of their own societies.

\section{Reflections on using participatory art as a method}

As there are no blueprints for how to conduct this type of study, and not all turns of fieldwork can be foreseen, many methodological decisions had to be made or remade during the time in field. At first, it was difficult to balance the artist's focus on aesthetic quality, the researcher's focus on substance, and the participants' focus on painting a correct "map," but as the fieldwork progressed, the respective roles got clearer. After 3-4 d, the discussions started to get saturated in terms of substance, at which point, we moved on, rather than adding details for the sake of aesthetic perfection. It was very valuable to involve an artist familiar with the local techniques, where to get supplies, and who spoke the participants' language. There is a risk that visualization techniques reinforce cultural bias and power relationships if they are unfamiliar to participants (Campbell 2002), so using a well-known art style and collaborating with a local artist skilled in both painting and instructing was essential. It was also helpful to have an interpreter who was familiar with the subject matter, as she could help facilitate the discussions.

The most challenging part of the painting process was to depict future aspirations. As opposed to painting the past and present, where consensus could be reached through discussion, it was difficult to produce a common vision for the future because aspirations and interests differ among groups and individuals (e.g., the continued presence of the companies). The activity was still valuable for spurring discussions around future change, but as always, it is important not to seek homogeneity among "local people"(White 1996). Here, we see big potential for methodological development, to add opportunities for more in-depth discussions about pathways to a desirable future. This could involve different groups (livelihoods, age, gender) and selected stakeholders working with environmental issues, community development, and human rights in the area. Rather than producing one vision, different future scenarios could be explored as part of an action-oriented process (Oteros-Rozas et al. 2015).

Another methodological challenge was to select participants for the painting workshops. When the idea to paint was introduced at the focus-group discussions, few volunteered to participate, simply because they had never painted before. But when we explained that an artist would instruct them, more people agreed to participate. After making the first painting, it also became clear that three participants were too many, making the group inactive as a whole. By reducing the group to two participants, all were active through the whole painting process and discussions. Most participants in the painting workshops were farmers, which might have affected the representation of other livelihoods in the painting. Efforts were made by the researcher to remind the participants of what had been said during the previous focus group, and by having additional focus-group discussions with fishermen and pastoralists to make sure that their stories were represented in the paintings.
Limiting the participants to two might seem to have made the research process less inclusive. However, the painting workshops enabled us to open up the conversation more broadly to people who had not been included in the focus-group discussions. As we were painting outside the village office, many people stopped by and were curious to see what we were doing and were encouraged to add something to the painting in order to increase the inclusiveness and richness of the knowledge production. Passersby also functioned as live peer reviewers by confirming, clarifying, or commenting on stories in the paintings. An example of this is passers-by discussing the past and the present, agreeing that they would prefer the present despite current challenges in terms of land availability, compared with the past when wild animals were the biggest threat to both lives and farming. Community members also tended to gather around the paintings, and participants explained the stories that were now visualized. This demonstrates the communicative qualities of using art for participatory knowledge production, as the paintings created a collaborative medium that enabled integrative communication (Clark et al. 2011, Zurba and Berkes 2013).

In addition to the communicative benefits of using art in the research process, the paintings themselves allow for communicating complexity in a way that generalized schematics or scientific texts cannot do in a condensed and readable way. This became particularly clear when we contrasted the generic schematic (Fig. 2) with the richness of the paintings, which simultaneously contain generalizable landscape-level trends such as forest-cover change and more context-specific processes observable only at the community or individual level. For example, increased participation of community members in company decisions could easily be represented in both paintings by people meeting under a mango tree, but would have been difficult to capture in a generalized schematic. The artwork has been used as boundary objects after the fieldwork in order to communicate local concerns to different stakeholders within and outside of academia through exhibitions at scientific conferences, open events, and at the National Museum and House of Culture in Dar Es Salaam, Tanzania.

\section{CONCLUSION}

In this study, we used participatory art in combination with conventional qualitative methods in order to coproduce knowledge about land-use change in villages affected by largescale land acquisitions in Kilombero Valley, Tanzania, aiming to understand experiences, perceptions, and drivers of socioenvironmental change. The paintings illustrate how communities are facing increased pressure on natural resources due to multiple stressors: population growth, land acquired by transnational agribusinesses, and expanded conservation areas. In its interactions with already existing pressures, land acquisitions should be understood as both a direct and indirect force behind socioenvironmental change, rather than an isolated phenomenon. Future aspirations differ, and many among the youth want the agribusiness to stay-but only if community members can get increased authority over company decisions and can benefit from their presence.

We found that painting workshops functioned as a valuable method for cocreating knowledge about the past, present, and future in the context of land-use change because they enabled us to understand and communicate the complexities of 
socioenvironmental change from a bottom-up perspective. Paintings functioned as boundary objects; a collaborative product that facilitated communication both between the researcher and affected communities and amongst community members. The art works have also been used as boundary objects after the fieldwork in order to communicate local concerns with regard to land acquisitions to different stakeholders within and outside of academia through exhibitions. Being a relatively novel approach, not least in this particular context, we encourage others to further explore the methodology to better understand its potentials and limitations.

Responses to this article can be read online at: http://www.ecologyandsociety.org/issues/responses. php/8986

\begin{abstract}
Acknowledgments:
We are indebted to LUCID (www.lucid.lu.se), a Linnaeus Centre of Excellence at Lund University funded by FORMAS (grant number 259-2008-1718). We are grateful for financial support from the Swedish Society for Anthropology and Geography ( $S S A G)$. We also want to acknowledge Anne Jerneck, Barry Ness, and Elsa Coimbra for fruitful input and discussions during the writing process.
\end{abstract}

\section{LITERATURE CITED}

Alden Wily, L. 2012. Looking back to see forward: the legal niceties of land theft in land rushes. Journal of Peasant Studies 39:751-775. http://dx.doi.org/10.1080/03066150.2012.674033

Boerma, P. 2012. Myths, memories and metaphors: recollecting landscape change in the Eritrean highlands. Journal of Eastern African Studies 6:246-269. http://dx.doi.org/10.1080/17531055.$\underline{2012.669573}$

Borras, S. M. Jr., R. Hall, I. Scoones, B. White, and W. Wolford. 2011. Towards a better understanding of global land grabbing: an editorial introduction. The Journal of Peasant Studies 38:209216. http://dx.doi.org/10.1080/03066150.2011.559005

Brandt, P., A. Ernst, F. Gralla, C. Luederitz, D. J. Lang, J. Newig, F. Reinert, D. J. Abson, and H. von Wehrden. 2013. A review of transdisciplinary research in sustainability science. Ecological Economics 92:1-15. http://dx.doi.org/10.1016/j.ecolecon.2013.04.008

Bryant, R. L. 1998. Power, knowledge and political ecology in the third world: a review. Progress in Physical Geography 22:79-94.

Brydon-Miller, M., D. Greenwood, and P. Maguire. 2003. Why action research? Action Research 1:9. http://dx.doi. org/10.1177/14767503030011002

Campbell, J. 2002. A critical appraisal of participatory methods in development research. International Journal of Social Research Methodology, 5, 19-29. http://dx.doi.org/10.1080/13645570110098046

Carothers, C., C. Brown, K. J. Moerlein, J. A. López, D. B. Andersen, and B. Retherford. 2014. Measuring perceptions of climate change in northern Alaska: pairing ethnography with cultural consensus analysis. Ecology and Society 19(4):27. http:// dx.doi.org/10.5751/es-06913-190427

Chambers, R. 1994. The origins and practice of participatory rural appraisal. World Development 22:953-969. http://dx.doi. org/10.1016/0305-750X(94)90141-4

Clark, W. C., T. P. Tomich, M. van Noordwijk, D. Guston, D. Catacutan, N. M. Dickson, and E. Mcnie. 2011. Boundary work for sustainable development: natural resource management at the Consultative Group on International Agricultural Research (CGIAR). Proceedings of the National Academy of Sciences of The United States of America 113(17):4615-4622. http://dx.doi. org/10.1073/pnas.0900231108

Cook, K. 2015. Grappling with wicked problems: exploring photovoice as a decolonizing methodology in science education. Cultural Studies of Science Education 10:581-592. http://dx.doi. org/10.1007/s11422-014-9613-0

Cornwall, A., and R. Jewkes. 1995. What is participatory research? Social Science and Medicine, 41:1667-1676. http://dx. doi.org/10.1016/0277-9536(95)00127-S

Cotula, L., C. Oya, E. A. Codjoe, A. Eid, M. Kakraba-Ampeh, J. Keeley, A. L. Kidewa, M. Makwarimba, W. M. Seide, and W. O. Nasha. 2014. Testing claims about large land deals in Africa: findings from a multi-country study. Journal of Development Studies 50:903-925. http://dx.doi.org/10.1080/00220388.2014.901501

Curtis, D. J. 2011. Using the arts to raise awareness and communicate environmental information in the extension context. The Journal of Agricultural Education and Extension 17:181-194. http://dx.doi.org/10.1080/1389224X.2011.544458

de Schutter, O. 2011. How not to think of land-grabbing: three critiques of large-scale investments in farmland. The Journal of Peasant Studies 38:249-279. http://dx.doi.org/10.1080/03066150.2011 .559008

Edelman, M. 2013. Messy hectares: questions about the epistemology of land grabbing data. Journal of Peasant Studies 40:485-501. http://dx.doi.org/10.1080/03066150.2013.801340

Enfors, E. I., L. J. Gordon, G. D. Peterson, and D. Bossio. 2008. Making investments in dryland development work: participatory scenario planning in the Makanya Catchment, Tanzania. Ecology and Society 13(2):42. http://dx.doi.org/10.5751/es-02649-130242

Foley, J. A., R. Defries, G. P. Asner, C. Barford, G. Bonan, S. R. Carpenter, F. S. Chapin, M. T. Coe, G. C. Daily, H. K. Gibbs, J. H. Helkowski, T. Holloway, E. A. Howard, C. J. Kucharik, C. Monfreda, J. A. Patz, I. C. Prentice, N. Ramankutty, and P. K. Snyder. 2005. Global consequences of land use. Science 309:570 574. http://dx.doi.org/10.1126/science. 1111772

Gaventa, J., and A. Cornwall. 2006. Challenging the boundaries of the possible: participation, knowledge and power. IDS Bulletin 37:122-128. http://dx.doi.org/10.1111/j.1759-5436.2006.tb00329. $\underline{\mathrm{x}}$

Gibbs, H. K., A. S. Ruesch, F. Achard, M. K. Clayton, P. Holmgren, N. Ramankutty, and J. A. Foley. 2010. Tropical forests were the primary sources of new agricultural land in the $1980 \mathrm{~s}$ and 1990s. Proceedings of the National Academy of Sciences 107 (38):16732-16737. http://dx.doi.org/10.1073/pnas.0910275107 
Glassman, M., and G. Erdem. 2014. Participatory action research and its meanings: vivencia, praxis, conscientization. Adult Education Quarterly 64:206-221. http://dx.doi.org/10.1177/0741713614523667

Hanspach, J., T. Hartel, A. I. Milcu, F. Mikulcak, I. Dorresteijn, J. Loos, H. von Wehrden, T. Kuemmerle, D. Abson, A. KovácsHostyánszki, A. Báldi, and J. Fischer. 2014. A holistic approach to studying social-ecological systems and its application to southern Transylvania. Ecology and Society 19(4):32. http://dx. doi.org/10.5751/es-06915-190432

Heras, M., and J. D. Tàbara. 2014. Let's play transformations! Performative methods for sustainability. Sustainability Science 9:379-398. http://dx.doi.org/10.1007/s11625-014-0245-9

Hunsberger, C., E. Corbera, M. Saturnino, S. M. Borras, Jr., R. de la Rosa, V. Eang, J. C. Franco, R. Herre, S. S. Kham, C. Park, D. Pred, H. Sokheng, M. Spoor, S. Thein, K. Thu, R. Thuon, C. Vaddhanaphuti, K. Woods, and C. Work. 2015. Land-based climate change mitigation, land grabbing and conflict: understanding intersections and linkages, exploring actions for change. MOSAIC Working Paper Series No. 1. MOSAIC: Climate change mitigation policies, land grabbing and conflict in fragile states: understanding intersections, exploring transformations in Myanmar and Cambodia. The Hague, The Netherlands.

Kangalawe, R. Y. M., and E. T. Liwenga. 2005a. Livelihoods in the wetlands of Kilombero Valley in Tanzania: opportunities and challenges to integrated water resource management. Physics and Chemistry of the Earth, Parts A/B/C 30:968-975. http://dx.doi. org/10.1016/j.pce.2005.08.044

Kangalawe, R. Y. M., and E. T. Liwenga. 2005b. Wetlands management in the Kilombero Valley, Tanzania. Pages 134-166 in H. Sosovele, J. B. F. M., editor. Social and environmental impact of irrigation farming in Tanzania. Dar es Salaam University Press Ltd., Dar es Salaam, Tanzania.

Kates, R. W., and T. M. Parris. 2003. Long-term trends and a sustainability transition. Proceedings of the National Academy of Sciences 100(14:8062-8067. http://dx.doi.org/10.1073/pnas.1231331100

Lambin, E. F., and P. Meyfroidt. 2011. Global land use change, economic globalization, and the looming land scarcity. Proceedings of the National Academy of Sciences 108:3465-3472. http://dx.doi.org/10.1073/pnas.1100480108

Lang, D. J., A. Wiek, M. Bergmann, M. Stauffacher, P. Martens, P. Moll, M. Swilling, and C. J. Thomas. 2012. Transdisciplinary research in sustainability science: practice, principles, and challenges. Sustainability Science 7:25-43. http://dx.doi. org/10.1007/s11625-011-0149-X

Locher, M., and E. Sulle. 2013. Foreign land deals in Tanzania: an update and a critical view on the challenges of data (re)production. The Land Deal Politics Initiative, The Hague, The Netherlands.

McGregor, S. E. 1976. Insect pollination of cultivated crop plants. Agricultural Research Service, U.S. Department of Agriculture, Agricultural Handbook 496.

Mombo, F., S. Speelman, G. van Huylenbroeck, J. Hella, M. Pantaleo, and M. Stein. 2011. Ratification of the Ramsar convention and sustainable wetlands management: situation analysis of the Kilombero Valley wetlands in Tanzania. Journal of Agricultural Extension and Rural Development 3:153-164.

National Bureau of Statistics (NBST). 2012. 2002 Census population distribution as per 2012 population census administrative units. National Bureau of Statistics, Tanzania. [online] URL: http: //http://www.nbs.go.tz/.

Nelson, F., E. Sulle, and E. Lekaita. 2012. Land grabbing and political transformation in Tanzania. Pages 17-19 in International Conference on Global Land Grabbing II, Ithaca, New York, 1719 October 2012. Land Deal Politics Initiative (LDPI), Cornell University, Ithaca, New York, USA.

Nightingale, A. J. 2003. A feminist in the forest: situated knowledges and mixing methods in natural resource management. ACME: an International E-journal for Critical Geographies 2(1):77-90.

Nightingale, A. J. 2015. Adaptive scholarship and situated knowledges? Hybrid methodologies and plural epistemologies in climate change adaptation research. Area 48(1):41-47. http://dx. doi.org/10.1111/area.12195

Oteros-Rozas, E., B. Martín-López, T. M. Daw, E. L. Bohensky, J. R. A. Butler, R. Hill, J. Martin-Ortega, A. Quinlan, F. Ravera, I. Ruiz-Mallén, M. Thyresson, J. Mistry, I. Palomo, G. D. Peterson, T. Plieninger, K. A. Waylen, D. M. Beach, I. C. Bohnet, M. Hamann, J. Hanspach, K. Hubacek, S. Lavorel, and S. P. Vilardy. 2015. Participatory scenario planning in place-based social-ecological research: insights and experiences from 23 case studies. Ecology and Society 20(4):32. http://dx.doi.org/10.5751/ ES-07985-200432

Oya, C. 2013. Methodological reflections on "land grab" databases and the "land grab" literature "rush." Journal of Peasant Studies 40:503-520. http://dx.doi.org/10.1080/03066150.2013 .799465

Pain, R., and P. Francis. 2003. Reflections on participatory research. Area 35(1):46-54. http://dx.doi.org/10.1111/1475-4762.00109

Palomo, I., B. Martín-López, C. López-Santiago, and C. Montes. 2011. Participatory scenario planning for protected areas management under the ecosystem services framework: the Doñana social-ecological system in southwestern Spain. Ecology and Society 16(1):23. http://dx.doi.org/10.5751/es-03862-160123

Riedlinger, D., and F. Berkes. 2001. Contributions of traditional knowledge to understanding climate change in the Canadian Arctic. Polar Record 37:315-328. http://dx.doi.org/10.1017/ $\underline{\mathrm{S} 0032247400017058}$

Rovero, F., and T. Jones. 2012. Wildlife corridors in the Udzungwa Mountains of Tanzania. Ecological Restoration 30(4):282-285. http://dx.doi.org/10.3368/er.30.4.282

Schneider, F., and S. Rist. 2013. Envisioning sustainable water futures in a transdisciplinary learning process: combining normative, explorative, and participatory scenario approaches. Sustainability Science 9:463-481. http://dx.doi.org/10.1007/ s11625-013-0232-6

Scoones, I., R. Hall, S. M. Borras, Jr., B. White, and W. Wolford. 2013. The politics of evidence: methodologies for understanding the global land rush. Journal of Peasant Studies 40:469-483. http://dx.doi.org/10.1080/03066150.2013.801341 
Shiklomanov, I. A. 2000. Appraisal and assessment of world water resources. Water International 25:11-32. http://dx.doi. org/10.1080/02508060008686794

Star, S. L., and J. R. Griesemer. 1989. Institutional ecology, translations, and boundary objects: amateurs and professionals in Berkeley's Museum of Vertebrate Zoology, 1907-39. Social Studies of Science 19:387-420. http://dx.doi.org/10.1177/03063$\underline{1289019003001}$

Streck, D. R. 2014. Knowledge and transformative social action: the encounter of selected traditions of participatory (action) research. Globalisation, Societies and Education 12:457-473. http://dx.doi.org/10.1080/14767724.2014.901907

Swart, R. J., P. Raskin, and J. Robinson. 2004. The problem of the future: sustainability science and scenario analysis. Global Environmental Change 14:137-146. http://dx.doi.org/10.1016/j. gloenvcha.2003.10.002

Toft, K. H. 2013. Are land deals unethical? The ethics of largescale land acquisitions in developing countries. Journal of Agricultural and Environmental Ethics 26:1181-1198. http://dx. doi.org/10.1007/s10806-013-9451-1

Turner, B. L., E. F. Lambin, and A. Reenberg. 2007. The emergence of land change science for global environmental change and sustainability. Proceedings of the National Academy of Sciences 104(52):20666-20671. http://dx.doi.org/10.1073/ pnas.0704119104

White, S. C. 1996. Depoliticising development: the uses and abuses of participation. Development in Practice 6:6-15. http://dx.doi. org/10.1080/0961452961000157564

Wiek, A., and D. Iwaniec. 2014. Quality criteria for visions and visioning in sustainability science. Sustainability Science 9:497512. http://dx.doi.org/10.1007/s11625-013-0208-6

Zoomers, A. 2010. Globalisation and the foreignisation of space: seven processes driving the current global land grab. The Journal of Peasant Studies 37:429-447. http://dx.doi.org/10.1080/03066$\underline{151003595325}$

Zurba, M., and F. Berkes. 2013. Caring for country through participatory art: creating a boundary object for communicating Indigenous knowledge and values. Local Environment 19:821836. http://dx.doi.org/10.1080/13549839.2013.792051 